\title{
The Predictors and Consequences of Personal Norms in Context of Organic Food Among Pakistani Consumers
}

\author{
Yawar Abbas Sandhu ${ }^{1}$, Selvan a/l Perumal ${ }^{2} \&$ Waida Irani Mohd Fauzi ${ }^{2}$ \\ ${ }^{1}$ Institute of Business Management Sciences, University of Agriculture, Faisalabad, Pakistan \\ ${ }^{2}$ School of Business Management, Universiti Utara Malaysia, Sintok, Kedah, Malaysia \\ Correspondence: Selvan a/l Perumal, School of Business Management, Universiti Utara Malaysia, Sintok, Kedah \\ Malaysia.
}

Received: April 20, 2019

Accepted: May 7, 2019

Online Published: May 19, 2019

doi:10.5430/ijfr.v10n3p314

URL: https://doi.org/10.5430/ijfr.v10n3p314

\begin{abstract}
Purpose- Primary aim of existing research is to detect the influence of environmental beliefs (awareness of consequences, injunctive social norms, environmental concern, environmental self-identity and aspiration of responsibility) on personal norms and subsequent effect thereof on organic food purchase intentions with mediation outcome of personal norms and moderating role of willingness to pay.

Design/methodology/approach- The data was collected from individual Pakistani consumers with 430 effective questionnaires. Further the responses were analysed through SPSS, V-22, Smart PLS-3.

Findings- The results showed that awareness of consequences, injunctive social norms, environmental concern, environmental self-identity and aspiration of responsibility showed significant influence to personal norms towards organic food. Subsequently, personal norms significantly affected organic food purchase intentions. Furthermore, willingness to pay for organic food proved to be positively significant moderator amongst personal norms and organic food purchase intentions.

Implications of Research- Present study helps out organic food marketers to apprehend customer demand for organic food from moral perspective and suggests the basis for the future development of organic food.

Originality- Present study is important for policy makers as it points out the ways to create awareness; secondly it also provides the schema to promote organically produced foods to consumers through messages based on morality.
\end{abstract}

Keywords: Personal norms, organic foods, Pakistani consumer purchasing intentions, environmental beliefs and willingness to pay.

\section{Introduction}

Environmental degradation and resultant effects on humans and other species have sensitise consumers in their buying decisions (do Paço et al., 2013). Now consumers are more informed and vigilant about their purchases (Furlow and Knott, 2009), hence, an inclination has been observed among consumers seeking environmentally friendly assortments (Jain and Kaur, 2006). This trend also has been observed in food selection food (Khare, 2015). Consumers are showing interest in buying organic food which is supposed to be more environmentally friendly and healthy as compared to its conventional counterpart (Ditlevsen et al., 2019). However, this inclination is more prominent in consumers belonging to developed nations (Asif et al., 2018). In developing countries, the concept of organic food is still in its initial phases; yet it is an important cluster for organic food due to the presence of huge population and increasing consumers' buying power (Basha and Lal, 2019). Similar case is Pakistan, where consumer preference for organic food is on rise (Al-Swidi et al., 2014). However, a recent empirical investigation of organic food purchase intentions among Pakistani consumers Asif et al. (2018) revealed that the consumers showed lower levels of support for such products and willingness to buy organic food were less influenced by promotional efforts. One possible explanation for this reluctance is the price, as organic food is higher priced compared to their counter parts (Sandhu et al., 2018). In view of discussed above findings demand for creating comprehensive understanding regarding factors influencing consumers' intentions to purchase organic food. This will enhance and enrich existing literature, further providing marketing implications in practical scenario helping out promotional campaign for eco-sustainable behaviour. Resultant knowledge would be of great importance particularly for 
emerging economies laden with of environmental issues. Further, organic food buying behaviour research in emerging nations context, like Pakistan, has gained less attention from past research, compared to the developed counterparts (Asif et al., 2018).

Pakistan stands as an important market in the South Asia, population counted near to 200 million (Pakistan Buru of Statistics, 2018). The rapid population growth and extensive use of pesticides for agriculture inputs have raised the environmental problems including water scarcity and contaminated underground water courses, air pollution, deforestation, barren lands, floods and shortage of natural resources in the last decade (World Bank, 2016). Therefore, the Government and social organizations are continuously in efforts improving environmental vigilance among individuals through policies, social and educational messages (Sandhu et al., 2018). Mostly, in past studies consumers' organic food buying behaviour have been analysed through rational decision-making models (Yadav and Pathak, 2016). However, Steg et al. (2014) argues that rationality is not the only case on which consumers buying decision is based, but there are personal moral motives that encourage consumers to make an altruistic decision. The activated personal norms enable a consumer to act pro-environmentally even at his or her personal cost (Shin et al., 2018). Furthermore, Stern et al. (1999) supports the argument that buying organic food is related to selfless and prosocial behaviour and rational actor models are unable to fully explain it. Norm Activation Theory; commonly known as (NAM); explains the selfless and environmentally friendly behaviour (Schwartz, 1977). Whereas, activation of personal moral norms is the heart of this theory, and consequently these intrinsic norms create behavioural intentions (Shin et al., 2018).

The current study investigates the activation of consumers' personal norms and resultant purchase intentions towards organic food in Pakistan. Theoretically, personal norms are based on consumers' pro-environmental beliefs i.e. (awareness of consequences, injunctive social norms, environmental concern, environmental self-identity and aspiration of responsibility). Further, this study also attempts to investigate the moderating effect of willingness to pay between the relationship of personal norms and purchase intentions. The study concentrates on various rational and moral factors emerged in prevalent theories focusing on environmentally friendly behaviour. Findings of existing study will help marketers to develop an effective design of pro-environmental campaigns and programmes based on moral and rational perspective facilitating buying organic food in Pakistani context.

\section{Literature Review and Hypotheses Development}

\subsection{Organic Food Purchase Intentions}

Previously, it is proved that the higher level of consumer's purchase intention toward a product predicts highly that the consumer will buy that product (Beyzavi and Lotfizadeh, 2014; Schiffman and Wisenblit, 2015). Further, Schiffman and Wisenblit (2015) conceptualised purchase intention as transection prone behaviour that a consumer encourages to perform after evaluating the product or a possibility to purchase, depending on the resultant consumer reaction towards the subjective product. Shah and Sayuti (2011) conceptualised purchase intention as an individual's capability to evaluate; either positive or negative; to a potential product buying situation. Organic food purchase intention refers to a consumer's tendency to buy an eco-friendly food which is considered environmentally friendly (Yadav and Pathak, 2016). Further, Misra and Singh (2016) conceptualised organic food purchase intention as an individual's willingness to prefer organic food in buying over to conventional alternatives due to its pro-environmental features. Organic food purchase intention is a complex phenomenon because it involves multiple cultural, social and personal characteristics so that it cannot be universally generalised (Peattie, 2001; Khare, 2015). The literature for organic food purchase intentions, speaks about a number of psychological and social factors that affect or create purchase intentions (Misra and Singh, 2016). Schwartz (1977) in his well-known Norm Activation Theory, commonly known as (NAM), endorses intent to behave as a proximal predictor of the behaviour, where intentions measure a person's inclination to perform an act.

\subsection{Norm Activation Theory}

Many studies in pro-environmental behaviour have tested and incorporated the NAM for the development of proposed conceptual frameworks (Shin et al., 2018). According to the NAM, behavioural intention is determined by personal norms and formerly personal norms are triggered by individual's environmental beliefs (Han et al., 2019). In the case of pro-environmental intentions, these beliefs and moral personal norms are tended to be supporting environmental safety and preservation. In NAM perspective behavioural intentions are based on the extent to which consumer is intrinsically and morally motivated to support an act which is prosocial and altruistic in nature. Moreover, these personal intrinsic sentiments are instigated by the beliefs as being aware of adverse consequences of a particular behaviour socially, and he or she aspires responsibility to avert those negative consequences (Schwartz, 1977). Furthermore, literature shows some other consumer belief as well that remains responsible to instigate 
environmentally supported personal norms, i.e. injunctive social norms, environmental concern and environmental self-identity. Injunctive social norms reflect an individual's belief regarding right things to do based on commonly acceptable conducts in the society (Doran and Larsen, 2016). Environmental concern describes the extent to which an individual is concerned of environmental safety and degradation. Environmental self -identity denotes a consumer's belief of self as being a pro-environmental individual who buys or consumes organic food. Empirical evidences demonstrate that the NAM's components diligently explained behavioural intentions for organic food choices, environmentally friendly products, recycling and electricity saving (Lindenberg and Steg, 2013; Shin et al., 2018; Han et al., 2019).

In the acknowledgement of extensive applicability of NAM, Steg et al. (2014) argue that NAM primarily focuses on the sense of morality, hence, effectively explains eco-friendly behaviour and makes choices impeded by efforts, time and money. The further extension in NAM is supported by Stern et al. (1999) as this theory has support and depth to explain unobservable phenomenon. Previously; in the extension of NAM; numerous studies have incorporated factors such as environmental consciousness, knowledge and emotions to predict pro-environmental behaviour (Polonsky, 1994; Hartmann and Apaolaza-Ibáñez, 2012; Onwezen, 2015; Dean et al., 2012). This incorporation has provided a comprehensive apprehension regarding various motives concerning pro-environmental consumption in the literature (Zhao et al., 2019). Therefore, the present study incorporates injunctive social norms, environmental self-identity and environmental concern in NAM model. Further, this study adds consumer's willingness to pay for eco-friendly food as a moderating variable among the relationship of consumers' personal moral norms and intentions to purchase organic food. Whereas, willingness to pay shows an individual's readiness to pay for organic food.

\subsection{Personal Norms}

Personal norms are an individual's conceptualisation of moral correctness or incorrectness of particular conduct and the conformance to which arouse the feelings of pride, while noncompliance provokes the feelings of guilt and shame (Onwezen, 2015). These are intrinsic values that evaluate a certain action if it is right or wrong (Bamberg and Möser, 2007). Personal norms are operationalised in past literature as ethical beliefs, personal norms and moral obligation (Sparks and Shepherd, 2002; Shin et al., 2018). Intentions and personal norms are distinct contracts from each other (Schwartz, 1977; Stern et al., 1999).

In their research about environmentally friendly travel modes Nordlund and Garvill (2003) found personal norms as positive and significant predictor of traveller's intention to use eco-friendly mode of transportation. Furthermore, in recent research, the adopters of vehicles sourced by alternative fuel were found scoring high for personal norms in the comparison of non-adopters (He and Zhan, 2018). However, Dolnicar and Grün (2009) found a weak relationship between moral obligation and various environmental protection intentions among tourists on vacations.

Hence, based on above stated literature review, following hypothesis has been formulated:

H1: Consumers' personal norms towards organic food are positively related to their organic food purchase intentions

\subsection{Awareness of Consequences}

Awareness of Consequences is an individual's belief and understanding about particular circumstances that pose a threat to other individuals or objects to whom an individual value (Schwartz, 1977). Several studies proved the assertion that awareness of consequences predict the pro-environmental personal norms (Gleim and Lawson, 2014; Han and Hwang, 2015; Joanes, 2019; Li and Wu, 2019, Shimoda et al., 2019). In the case of organic food most of the studies in the past have operationalized this construct to measure consumers' awareness of consequences as unidimensional construct i.e. environment-related consequences (Stern et al., 1999, Shin et al., 2018), however, Magnusson et al. (2003) reported its significance as multidimensional construct such as awareness of environment and social health related consequences. These two dimensions of awareness of consequences are important in the context of organic food. The results found multidimensional awareness of consequences as a significant predictor of personal norms as altruistic behaviour for organic food is triggered by an individual's perception of consequences for both environmental and social health (Magnusson et al., 2003). Following the recommendation by Magnusson et al. (2003) this study incorporates awareness of consequences as a $2^{\text {nd }}$ order construct with two dimensions; environment and social health-related consequences.

H2: Consumer's awareness of consequences is positively related to their personal norms towards organic food

\subsection{Injunctive Social Norms}

Injunctive social norms are the social norms which refer to an individual's belief and define what the people should 
do in a given circumstance to get conformance with the optimistic anticipations of significant others (Jacobson et al., 2015). Similarly, injunctive social norms represent certain beliefs and guidelines to which people adhere to avoid sanctions. Instead of self-driven personal benefits, these injunctive social norms are based on avoidance of perceived punishment and sanctions related to norm violation (Hornsey et al., 2003), hence, an individual gets motivated by a desire to fulfil his responsibility, abide regulation and avoid any disapproval (Cialdini and Trost, 1998; Doran and Larsen, 2016).

According to Schwartz (1977) and Stern et al. (1999), personal norms are internalised social norms. Whereas, Doran and Larsen (2016) asserted that injunctive social norms instigate the sense of moral obligation that resultantly activate personal norms. Further, the personal norms are intrinsically activated by one's self-expectation concerning morally adequate action (Han et al., 2017), and at parallel, conforming to group-based standards or others' expectation, instigate personal norms (Smith et al., 2012; Cestac et al., 2014). Hence, Personal norm activation is subject to intrinsic and social normative extrinsically based personal motives. Many studies have postulated the positive link of injunctive social norms and consumers personal moral obligation to choose eco-friendly travelling mode (Doran and Larsen, 2016), selection of green hotels (Han et al., 2015) and practising grass-cycling (White and Simpson, 2013). However, the interaction between injunctive social norm, personal norms and purchase intention relationship is yet to be tested in an organic food context. Hence, this study proposes following hypothesis:

H3: Consumers' injunctive social norms are positively related to their personal norms towards organic food

\subsection{Environmental Concern}

Environmental concern measures to the extent that an individual is aware of environmental problems in general and offers support for corrective measures and ensures personal involvement for an intended solution (Dunlap and Jones, 2002). Schultz et al. (2005) argued that environmental concern is rooted in a person's value system (Stern and Dietz, 1994); that is people are concerned for environmental problems when these problems threaten things individual values (Steg et al., 2014). Higher consumer's environmental concern is based on strong biospheric values; these values further motivate a person intrinsically to involve himself or herself in pro-environmental behaviour (De Groot and Steg, 2009). While acting in the line with value-based environmental concern stimulates the feelings of self-esteem, pride and self-satisfaction (Onwezen, 2015). Environmental concern is less general than values, however, it is based on inherent values system aspired by an individual (Joireman et al., 2001; Schultz, 2001). Hence, environmental concern associates strongly with personal norms (Steg et al., 2011). Alternatively, some studies view environmental concern to be less successful in explaining personal norms and acceptability judgments than values (Schultz 2001; Lee et al., 2009; Englis and Phillips, 2013). Therefore, the results from previous literature for environmental concern and personal norm link are mixed and inconclusive.

Based on above mentioned literature, the following hypothesis is proposed:

H4. Consumer's environmental concern positively relates to personal norms towards organic food

\subsection{Environmental Self-identity}

Environmental self-identity is defined as the way people form their self-concept in connection to nature and the environment; hence, a belief emerges within themselves that the environment is important to all and is an important part of who they are (Whitmarsh and O'Neill, 2010; Hansen et al., 2018). Furthermore, self-identity divulged in environmental way is the view point where an individual articulates oneself as environment friendly person (Van der Werff et al., 2013). Previously, particularly in environmental psychology, the studies have analysed the impact of specified self-identities on consumer behaviour which are consistent with those identities. For instance, self-identity towards saving energy promotes intentions to save energy (van der Werff et al., 2013), specific perceived identity to be recycler encourages an individual towards recycling act (Nigbur et al., 2010), the identity of being activist in environmental way prompts a person towards environmental activism (Fielding et al., 2008) and the identity realised as a consumer of organic dietary products motivates an individual to consume organic food (Hansen et al., 2018). Moreover, environmental self-identity relates to a person's motivation intrinsically encouraging one in eco-friendly manners, resultantly eco-centric action be performed by the individual (Sandhu et al., 2018; Peloza et al., 2013; Van der Werff et al., 2013). Environmental self-identity implies activation of personal norms to act in sustainable manners because non-sustainable behaviour threatens valuable self-identity and self-esteem (Whitmarsh and O'Neill, 2010). Therefore, following hypothesis has been proposed:

H5: Consumer's environmental self-identity positively relates to their personal norms towards organic food

\subsection{Aspiration of Responsibility}


Aspiration of Responsibility is defined as social and psychological belief where an individual realises the feelings of responsibility (social or environmental) about problems caused by his or her behaviour (Steg and De Groot, 2010). On the other hand, Stern et al. (1999) conceptualize aspiration of responsibility as a pro-environmental belief that defines an individual's feeling of held responsible for adverse circumstances of not acting eco-friendly way and consequently a group of people or things are facing threat and that he or she can do something to elevate that threat (De Groot and Steg, 2009). Stem from qualitative research in the domain of organic food to explore the factors that contribute towards purchase decision, suggests that the consumers sometimes relate feelings of good conscience and feelings of responsibility to the well-being of their family and others, particularly in the case of buying organic food (Zanoli, 2004). A situation in which the individual is aware of the fact that the wellbeing of others depends upon his or her act, in return the individual feels responsible for his or her action and resultant consequences, hence, can be classified as personal norms (Schwartz, 1977; Davies et al., 2002).

According to the above analysis, the following hypothesis is proposed:

H6: Consumer's aspiration of responsibility positively relates to personal norms towards organic food

Further, this study suggests the mediating role of consumers personal norms towards organic food between the relationship of awareness of consequences, injunctive social norms. Environmental concern, environmental self-identity, aspiration of responsibility and organic food purchase intentions.

H7: Consumer personal norms positively mediate the relationship between awareness of consequences and purchase intention towards organic food

H8: Consumer personal norms positively mediate the relationship between injunctive social norms and purchase intention towards organic food

H9: Consumer personal norms positively mediate the relationship between environmental concern and purchase intention towards organic food

H10: Consumer personal norms positively mediate the relationship between environmental self-identity and purchase intention towards organic food

H11: Consumer personal norms positively mediate the relationship between aspiration of responsibility and purchase intention towards organic food

\subsection{Willingness to Pay}

Willingness to pay is defined as the premium payoff that a consumer wish to offer for a product, or else, this is the amount that makes a person in-different purchasing or abstaining a product (Le Gall, 2009). In past research it is validated that individual's financial resources proved to be a critical self-capability particularly in the case of eco-friendly buying (Tully and Winer, 2014). Consumers indeed, show inclination towards paying higher prices for hazards free food and diet (Zepeda and Li, 2007; Roitner-Schobesberger et al., 2008; Paul and Rana, 2012). Organic food is considered to be a premium priced product competitively, therefore willingness to pay premium prices are a better indicator for purchase intentions (Tung et al., 2012). The pricing factor strongly influences consumer's decision making for green products (Osterhus, 1997). The past studies showed a positive link between personal norm and stated willingness to pay for green products including organic food products (Spash et al., 2009; Voon et al., 2011; Bishop and Barber, 2015). In the past studies, WTP has been used as a moderator between the relationships of attitude and eco-friendly purchase intentions (Berger et al., 1994; Ling, 2013).

It is, therefore, imperative to assess the impact of WTP as a moderator on the relationship between consumer's personal norms and organic food purchase intentions. As suggested by Baron and Kenny (1986), a moderating variable is introduced where the relationships between independent variables and the dependent variable are inconsistent or vague. A review of previous literature for this study suggests that the impact of personal norms on purchase intentions is inconsistent (Magnusson et al., 2001; McEachern and Mcclean, 2002; Thøgersen et al., 2015; Yadav and Pathak, 2017). Based on the suggestions for utilisation of a moderating variable to elaborate inconsistencies (Baron and Kenny, 1986) and the usability of potential moderator (Ling, 2013; Moser, 2015; Persaud and Schillo, 2017; Hansen et al., 2018), this study considers the moderating effect of WTP for further understanding of the objective relationship.

In the light of above stated statements this study following hypotheses:

H12: Consumer's willingness to pay moderates positively the relationship between personal norms and organic food 
purchase intentions.

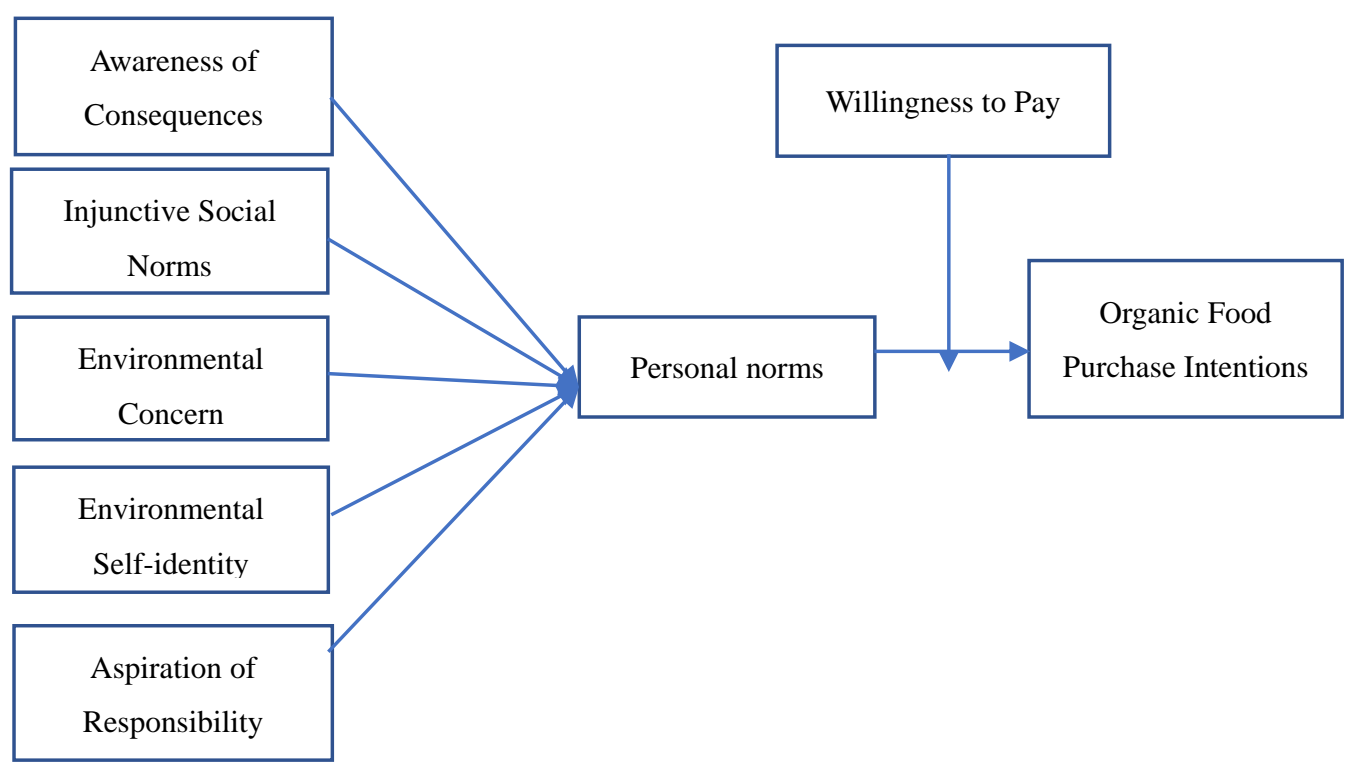

Figure 1. Research framework

\section{Methodology}

Present research follows the quantitative approach. Numerous researchers find this process robust to see trends or relationships among variables, theories, models and hypotheses (Creswell, 2013). The current study aims to test the influence of pro-environmental beliefs on personal norms and subsequent intentions to purchase organic food, whereas personal norms mediate the relationship. Further, it examines the moderating roles of willingness to pay among the link of personal norms and organic food purchase intentions. Thus, it requires the collection of numerical data to test the relationships mentioned above. For this purpose, the use of quantitative research is ideal for the study. Questionnaires were used for data collection. These questionnaires were in English language, in line with Asif et al. (2018) and same was administered to the respondents randomly.

\subsection{Research Measures}

The study measures the consumers' personal norms through six item scale adapted from Abrahamse et al. (2009). The personal norms refer to consumers' sense of realising intrinsic obligation to buy pro-environmental organic food products. Five items for measuring Injunctive social norm were adapted from Vermeir and Verbeke (2008). These items elicited respondents' perceptions to which a specific behaviour is commonly accepted or not (Cojuharenco et al., 2016). To measure awareness of consequences, 13 items were adapted from studies by Magnusson et al. (2003). It is operationalized as $2^{\text {nd }}$ order construct representing two dimensions of awareness of consequences (environment and social health related). These items sought respondents' sense of awareness regarding the negative consequences on environment and social health due to chemically intensive agriculture practices and conventional food products. Environmental self-identity is measured by five items adapted from Hustvedt and Dickson (2009). These items measure the consumer's ability seeing himself or herself as an environmentally-friendly person and likely to purchase organic food products because it is important to all and an important part of who he or she is. Further, environmental concern is measured by 5 items adapted from Yadav and Pathak (2016). These items measure the extent to what the consumer concern for environmental care influence his or her intentions to buy green products. Aspiration of responsibility is measured by 5 items scale adapted from Han and Hwang (2016). Aspiration of responsibility refers to the feelings of responsibility that an individual aspires due to the adverse effects of chemically intensive 'non-organic' conventional food products on others people's health and the environment. Willingness to pay is measured through 4 items scale adapted by Trivedi et al. (2015). The scale items measure an individual's inclination to pay for organic food. Finally, Organic food purchase intentions are measured by six item scale adopted from Wee et al. (2014). Please see appendix for questionnaire items. The items operationalizing the constructs were measured using a 5-point scale. To measure purchase intentions, personal norms, awareness of 
consequences, injunctive social norms, environmental concern, environment self-identity and aspiration of responsibility and willingness to pay, the scale was anchored at 1 for 'strongly disagree', and 5 for 'strongly agree'.

\subsection{Study Sites and Sampling}

This study used mall intercept data collection method, whereas, shopping malls and respondents were sampled through cluster sampling. The respondents in this study were Pakistani consumers aged between 18 years and above who were contacted randomly when they were visiting shopping malls (Emporium mall, Dolmen Mall, City tower, millennium mall and centaurs tower) in five cities in Pakistan including four provincial capitals (Lahore, Karachi, Peshawar and Quetta) and federal capital Islamabad respectively. A survey instrument was administered to consumers while they were shopping by the researcher and two enumerators. A total number of 540 consumers were contacted to perform the survey, however, 450 responded. During the data screening, there were 20 surveys found incomplete these questionnaires were eliminated. Hence, the total number of valid cases for the survey was 430 which included 157 females (36.5\%) and 273 males (63.5\%).

\subsection{Statistical Analysis}

In the current study, the collected data was further analysed with descriptive and inferential statistics by SPSS v.22. Afterwards, for complex analysis, Partial Least Squares Structural Equation Modelling approach (PLS-SEM) was used by SmartPLS-3.

\subsubsection{Detection of Outliers}

To detect outliers, frequency tables of minimum and maximum values for all variables were used. An initial analysis of these frequency tables revealed that no values were found to be excessively outside the acceptable range. Furthermore, attempts were made to detect multivariate outliers using Mahalanobis distance $\left(\mathrm{D}^{2}\right)$. Mahalanobis distance $\left(\mathrm{D}^{2}\right)$ is defined as "the distance of a case from the centroid of the remaining cases where the centroid is the point created at the intersection of the means of all the variables" (Tabachnick et al., 2012). Based on 7 predictor variables of the study, degree of freedom at 7 , and the using probability critical value method, Mahalanobis values were calculated and probability value examined through cdf Chi square (Tabachnick et al., 2012) with the help of linear regression method in SPSS v22. 2 cases were identified showing probability value probability value less than 0.001 cut-off value. These two cases were removed. Therefore 428 responses were used for further data analysis.

\subsubsection{Assumption of Normality}

After detecting and removing outliers, the normality of the collected data was assessed. The assessment of the normal distribution of scores for independent and dependent variables can be obtained by accessing skewness and kurtosis values as suggested by Pallant (2005). According to Kline (1998) the cut-off value for skewness and kurtosis may fall within the range of -3 and +3 . There are some kurtosis values (i.e., awareness of consequences and willingness to pay) in this study not within the range of -3 and +3 as shown in Table 1 .

According to results some kurtosis and skewness values show a deviation from normal distribution. Therefore, this study employed PLS-SEM. This is because PLS does not require normally-distributed input data.

Table 1. Result for Skewness and Kurtosis for normality test

\begin{tabular}{|c|c|c|c|c|}
\hline \multirow[t]{2}{*}{ Factors } & \multicolumn{2}{|c|}{ Skewness } & \multicolumn{2}{|l|}{ Kurtosis } \\
\hline & Statistic & Standard Error & Statistic & Standard Error \\
\hline Purchase Intentions & -1.216 & .118 & 2.609 & .235 \\
\hline Personal norms & -1.046 & .118 & 1.905 & .235 \\
\hline Willingness to pay & -1.229 & .118 & 3.015 & .235 \\
\hline $\begin{array}{l}\text { Awareness of } \\
\text { environment related }\end{array}$ & -1.193 & .118 & 3.960 & .235 \\
\hline $\begin{array}{l}\text { Awareness of consequences social } \\
\text { health related }\end{array}$ & -1.024 & .118 & 3.046 & .235 \\
\hline Injunctive Social Norms & -1.216 & .118 & 2.907 & .235 \\
\hline Environmental Concern & -1.352 & .118 & 2.439 & .235 \\
\hline
\end{tabular}




\begin{tabular}{lllll}
\hline Factors & \multicolumn{2}{l}{ Skewness } & Kurtosis & \\
\cline { 2 - 5 } & Statistic & Standard Error & Statistic & Standard Error \\
\hline Environmental Self-identity & -0.765 & .118 & 1.051 & .235 \\
\hline Aspiration of Responsibility & -1.055 & .118 & 2.229 & .235 \\
\hline
\end{tabular}

\subsubsection{Partial Least Square (PLS) Structural Equation Modeling Approach}

Partial least squares (PLS) method is applied for evaluation of the mediating effects of personal norms on the relationships between environmental beliefs and consumer purchase intentions and moderating role of willingness to pay among the relationship of personal norms and purchase intentions in respect of organic food in Pakistan through SmartPLS version 3.0. PLS, as it is less sensitive to multivariate normal distribution data (Chin, 1998). In this study, bootstrapping analysis of 5000 sub-samples was used for estimation.

\subsection{Analysis of Measurement Model}

Using Smart PLS, in the first step, the measurement model (outer model) was examined to ascertain the appropriateness of loadings of the indicators (items) on the theoretically devised respective constructs. Outer model is evaluated in order to affirm that items measure the construct they were supposed to measure, consequently ascertaining that the instrument used is reliable. Furthermore, the analysis involves testing one second-order construct (Awareness of Consequences and all other constructs in the study are treated as first order constructs. Awareness of consequences including two dimensions of awareness of consequences (environment related and social health related). In the present study, there are eight latent variables which included five independent variables (Awareness of Consequences, Injunctive Social Norms, Environmental Concern, Environmental Self-identity, Aspiration of Responsibility), one mediating variable (Personal norms), one moderating variable (willingness to pay) and one dependent variable (Purchase intentions). Originally, the study model has included 49 reflective measurement items.

Convergent validity is the degree to which the measure correlates positively with other measures of the same construct (Hair et al., 2016). Further, in order to confirm convergent validity, the factor loadings and average variance extracted (AVE) were analysed through SmartPLS-3. Inter construct reliability is an important measure to analyse convergent validity. The construct reliability is assessed through cronbach's alpha $(\alpha)$ and composite reliability (CR). As per Table 2, 8 items (ACEnv1, ACEnv5 ACEnv7, ACEnv8, PN5, WTP3, AR3, AR4) were removed due to inter construct item factor loadings below 0.6. Furthermore, the AVE values of study measures were also been analysed ranging between 0.51 and 0.66 , proved to be above the standard values recommended by Hair et al. (2016) i.e. 0.5. Thus, AVE values show a good level of construct validity (Barclay et al., 1995). Moreover, in order to assert convergent validity, the $(\alpha)$ value must be or above 0.70 (Hair et al., 2016). Table 2 displays that $(\alpha)$ for all constructs resulted above the value of 0.70 and appeared to be ranged between 0.710 and 0.840 . This fact ensures the construct reliability. The final test to establish convergent validity was testing composite reliability (CR). According to Hair et al. (2016), CR value should fall at or above 0.7. As far as construct CR is concerned the values showing a range in between 0.801 and 0.882 , exceeding well of standard value of 0.70 . Hence, analysed CR values affirm convergent validity of study's outer model or measurement model.

Table 2. Reliability (factor loading, Cronbach's alpha, composite reliability and AVE)

\begin{tabular}{llllll}
\hline Factors & Items & $\begin{array}{l}\text { Standardized } \\
\text { Factor } \\
\text { Loading }\end{array}$ & $\begin{array}{l}\text { Cronbach's } \\
\text { Alpha }\end{array}$ & Composite Reliability & $\begin{array}{l}\text { Average Variance Extracted } \\
\text { (AVE) }\end{array}$ \\
\hline $\begin{array}{l}\text { Awareness of } \\
\text { Consequences } \\
\text { Environmental }\end{array}$ & ACEnv2 & 0.729 & 0.710 & 0.821 & 0.534 \\
\cline { 2 - 6 } & ACEnv3 & 0.741 & & & \\
\cline { 2 - 6 } & ACEnv4 & 0.715 & & & 0.513 \\
\hline \multirow{2}{*}{$\begin{array}{l}\text { Awareness of } \\
\text { Consequences }\end{array}$} & ACSoc1 & 0.700 & 0.763 & 0.840 & \\
\cline { 2 - 6 } & ACSoc2 & 0.711 & & & \\
\hline
\end{tabular}




\begin{tabular}{|c|c|c|c|c|c|}
\hline Factors & Items & $\begin{array}{l}\text { Standardized } \\
\text { Factor } \\
\text { Loading }\end{array}$ & $\begin{array}{l}\text { Cronbach's } \\
\text { Alpha }\end{array}$ & Composite Reliability & $\begin{array}{l}\text { Average Variance Extracted } \\
\text { (AVE) }\end{array}$ \\
\hline \multirow[t]{3}{*}{ Social } & ACSoc3 & 0.710 & & & \\
\hline & ACSoc4 & 0.721 & & & \\
\hline & ACSoc5 & 0.728 & & & \\
\hline \multirow{3}{*}{$\begin{array}{l}\text { Aspiration of } \\
\text { Responsibility }\end{array}$} & AR1 & 0.804 & 0.743 & 0.853 & 0.659 \\
\hline & AR2 & 0.838 & & & \\
\hline & AR5 & 0.791 & & & \\
\hline \multirow{5}{*}{$\begin{array}{l}\text { Environmental } \\
\text { Concern }\end{array}$} & $\mathrm{EC} 1$ & 0.790 & 0.803 & 0.856 & 0.545 \\
\hline & $\mathrm{EC} 2$ & 0.686 & & & \\
\hline & EC3 & 0.685 & & & \\
\hline & $\mathrm{EC} 4$ & 0.710 & & & \\
\hline & EC5 & 0.811 & & & \\
\hline \multirow{5}{*}{$\begin{array}{l}\text { Environmental } \\
\text { Self-Identity }\end{array}$} & ESI1 & 0.730 & 0.782 & 0.851 & 0.533 \\
\hline & ESI2 & 0.755 & & & \\
\hline & ESI3 & 0.731 & & & \\
\hline & ESI4 & 0.703 & & & \\
\hline & ESI5 & 0.729 & & & \\
\hline \multirow{5}{*}{$\begin{array}{l}\text { Injunctive } \\
\text { Social Norms }\end{array}$} & ISN1 & 0.703 & 0.763 & 0.837 & 0.509 \\
\hline & ISN2 & 0.763 & & & \\
\hline & ISN3 & 0.609 & & & \\
\hline & ISN4 & 0.779 & & & \\
\hline & ISN5 & 0.700 & & & \\
\hline \multirow{6}{*}{$\begin{array}{l}\text { Purchase } \\
\text { Intentions }\end{array}$} & PI1 & 0.790 & 0.840 & 0.883 & 0.556 \\
\hline & PI2 & 0.741 & & & \\
\hline & PI3 & 0.722 & & & \\
\hline & PI4 & 0.726 & & & \\
\hline & PI5 & 0.766 & & & \\
\hline & PI6 & 0.726 & & & \\
\hline \multirow[t]{5}{*}{ Personal norms } & PN1 & 0.710 & 0.761 & 0.839 & 0.511 \\
\hline & PN2 & 0.679 & & & \\
\hline & PN3 & 0.725 & & & \\
\hline & PN4 & 0.709 & & & \\
\hline & PN6 & 0.733 & & & \\
\hline \multirow{3}{*}{$\begin{array}{l}\text { Willingness to } \\
\text { Pay }\end{array}$} & WTP1 & 0.871 & 0.717 & 0.839 & 0.637 \\
\hline & WTP2 & 0.688 & & & \\
\hline & WTP4 & 0.824 & & & \\
\hline
\end{tabular}

\subsubsection{Discriminant Validity}

The next phase is to confirm scale's discriminant validity. Discriminant validity ensures the discrimination of one 
construct of the study with others. Meaning no two constructs are measuring same thing (Hair et al., 2016). Existing study evaluate discriminant validly with the help of Heterotrait-Heteromethod matrix (HTMT) approach. Traditionally, discriminant validity is analysed through Fornell-Larcker Criterion and cross ladings. However, these both measures display lower level of sensitivity towards discriminant validity, hence, demand for other statistically rigorous criterion alternatively. HTMT approach links back to classical multi-trait multimethod (MTMM) matrix proposed by Campbell and Fiske, (1959) as cited by Voorhees et al. (2016). Further, HTMT enables discriminat validity in systematic manners ensuring construct validity properly. HTMT assess average correlation of study construct confirming all the constructs of interest must quantify different phenomena under study. Observed construct must not be highly corelated. Statically, HTMT values for reflective constructs must be at 0.90 or below of that (Henseler et al., 2015). Following two tables 3 and 4 presenting HTMT ratio for $1^{\text {st }}$ order and $2^{\text {nd }}$ order constructs separately respectively.

Subsequently, table 3 and 4 show none of the value in HTMT matrix is higher than 0.9 (Henseler, et al., 2015), hence the discriminant validity of study construct is established. After getting acceptable results for the measurement model, i.e., establishing reliability and validity of the study's constructs, the next step was to assess the structural model.

Table 3. HTMT criterion for $1^{\text {st }}$ order

\begin{tabular}{|c|c|c|c|c|c|c|c|c|c|}
\hline & ACEnv & ACSoc & AR & $\mathrm{EC}$ & ESI & ISN & PI & PN & WTP \\
\hline \multicolumn{10}{|l|}{ ACEnv } \\
\hline ACSoc & 0.553 & & & & & & & & \\
\hline AR & 0.237 & 0.29 & & & & & & & \\
\hline EC & 0.322 & 0.333 & 0.2 & & & & & & \\
\hline ESI & 0.233 & 0.246 & 0.494 & 0.194 & & & & & \\
\hline ISN & 0.295 & 0.321 & 0.269 & 0.226 & 0.359 & & & & \\
\hline PI & 0.406 & 0.463 & 0.405 & 0.473 & 0.42 & 0.547 & & & \\
\hline $\mathrm{PN}$ & 0.319 & 0.375 & 0.596 & 0.261 & 0.554 & 0.427 & 0.597 & & \\
\hline WTP & 0.169 & 0.326 & 0.341 & 0.138 & 0.320 & 0.369 & 0.289 & 0.364 & \\
\hline
\end{tabular}

Table 4. HTMT criterion for $2^{\text {nd }}$ order

\begin{tabular}{|c|c|c|c|c|c|c|c|c|}
\hline & $\mathrm{AC}$ & $\mathrm{AR}$ & $\mathrm{EC}$ & ESI & ISN & PI & $\mathrm{PN}$ & WTP \\
\hline \multicolumn{9}{|l|}{$\mathrm{AC}$} \\
\hline $\mathrm{AR}$ & 0.307 & & & & & & & \\
\hline $\mathrm{EC}$ & 0.379 & 0.2 & & & & & & \\
\hline ESI & 0.277 & 0.494 & 0.194 & & & & & \\
\hline ISN & 0.357 & 0.269 & 0.226 & 0.359 & & & & \\
\hline PI & 0.505 & 0.405 & 0.473 & 0.42 & 0.547 & & & \\
\hline $\mathrm{PN}$ & 0.404 & 0.596 & 0.261 & 0.554 & 0.427 & 0.597 & & \\
\hline WTP & 0.296 & 0.341 & 0.138 & 0.320 & 0.369 & 0.289 & 0.364 & \\
\hline
\end{tabular}

\subsubsection{The Structural Model}

After ensuring validity and reliability of measurement model or inner model, the study structural model or outer model was assessed. In this process path coefficient among constructs was analysed through SmartPLS-3 (Henseler et al., 2015). The analysing process involves standard bootstrapping to determine the significance of path coefficients where 428 cases were evaluated with 5,000 sub-samples bootstrapped. (Hair et al., 2016). The structural model estimates representing intervening variables (i.e., consumer personal norms and willingness to pay and consumers) are detailed in Figure 1. 
Structural model, i.e., path coefficient was tested by running PLS Algorithm using SmartPLS 3.0. The path coefficient (refer to Figure 1) represents the hypothesized relationship between the constructs and its standardized value is between -1 and +1 (Hair et al., 2016).

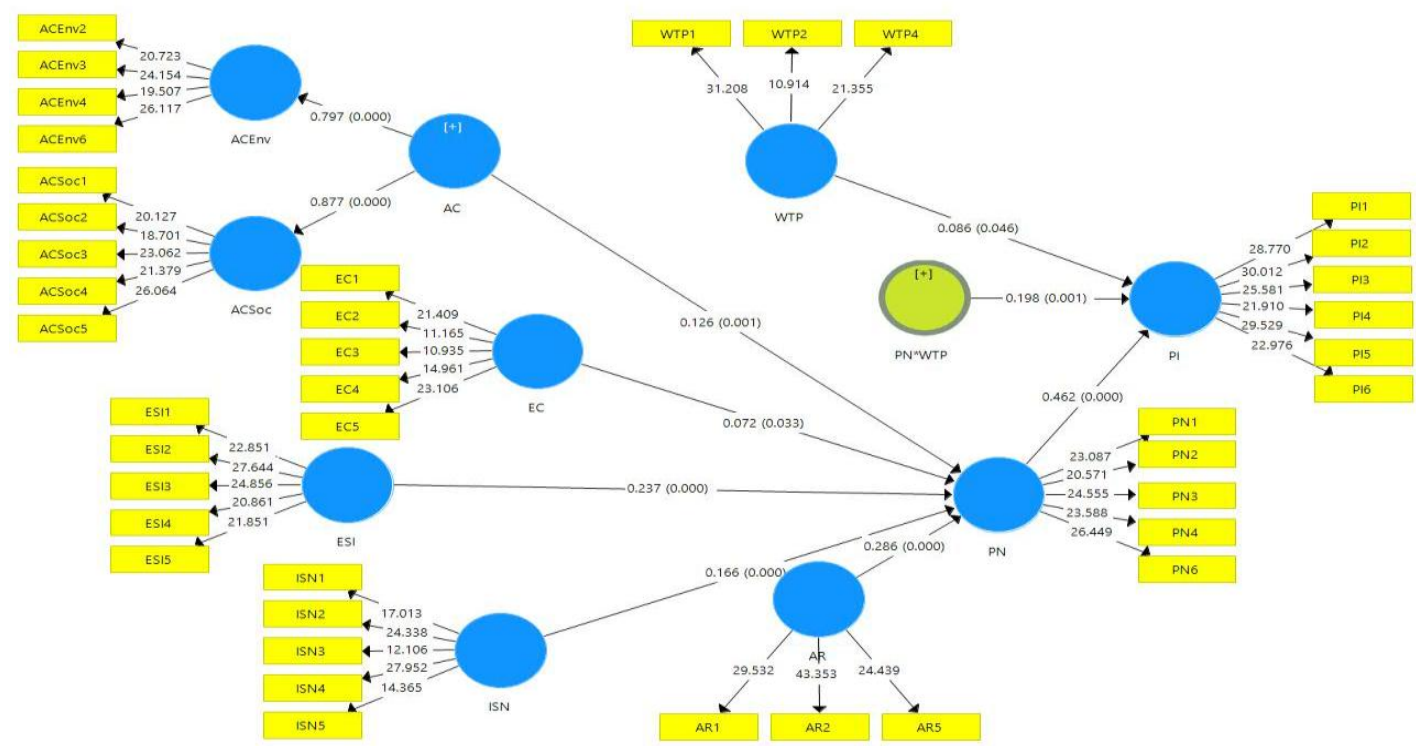

Figure 1

Note: PI- Purchase Intentions; PN- Personal norms; AC- Awareness of Consequences; ACEnv- Awareness of Consequences environmental; ACSoc- Awareness of consequences social; ISN- Injunctive Social Norms; ECEnvironmental Concern; ESI- Environmental Self-identity; AR- Aspiration of Responsibility; WTP- Willingness to Pay.

\subsubsection{R Square}

Coefficient of determination $\left(\mathrm{R}^{2}\right)$ of endogenous latent variable is perhaps the most commonly used criteria for assessing structural model (Hair et al., 2016). As per Cohen (1988), $\mathrm{R}^{2}$ value of 0.27 indicates substantial, 0.13 indicates moderate, and 0.02 indicate weak $\mathrm{R}^{2}$ values. Results show that the $\mathrm{R}^{2}$ value of consumer personal norms $(0.346)$ are substantial value whereas purchase intentions (0.285) shows substantial value as well. The two $\mathrm{R}^{2}$ values in this study indicate that all five exogenous variables (awareness of consequences, injunctive social norms, environmental concern, environmental self-identity and aspiration of responsibility) collectively explain $34.6 \%$ of variance in the mediating variable (i.e., personal norms) and the overall $\mathrm{R}^{2}$ value indicates that all seven exogenous variables i.e. (awareness of consequences, injunctive social norms, environmental concern, environmental self-identity and aspiration of responsibility, personal norms and willingness to pay) collectively explain $28.5 \%$ of variance in the endogenous variable (i.e., purchase intention). This follows that the model has substantial predictive validity based on the assessment of the $\mathrm{R}^{2}$ values of the endogenous latent variables, consumer personal norms (0.346) and purchase intention (0.285).

\subsubsection{F Square}

After coefficient evaluation, Hair et al. (2016) suggests assessing the effect size $\left(\mathrm{f}^{2}\right)$. Effect size refers to the difference in $\mathrm{R}^{2}$ before and after inclusion of a particular exogenous construct from the model. According to Cohen (1988), an obtained value of 0.02 indicates small effect, a value of 0.15 indicates a moderate effect and a value of 0.35 indicates a large effect. However, Chin et al. (2003) have asserted that even the smallest effect size ( $\mathrm{f}^{2}$ ) should be reported as it can impact the endogenous latent variables. 
Table 5

\begin{tabular}{lll}
\hline Effect Size of Exogenous Variable & f-squared & Effect size \\
\hline Personal norms & 0.277 & Moderate Effect \\
\hline Awareness of Consequences & 0.020 & Small Effect \\
\hline Injunctive Social Norms & 0.036 & Small Effect \\
\hline Environmental Concern & 0.007 & Very Small Effect \\
\hline Environmental Self-identity & 0.069 & Very Small Effect \\
\hline Aspiration of Responsibility & 0.103 & Small Effect \\
\hline
\end{tabular}

As indicated in Table 5, the effect size of personal norm on purchase intention is 0.277 and the effect sizes for awareness of consequences, injunctive social norms, environmental concern, environmental self-identity and aspiration of responsibility on personal norms were $0.020,0.036,0.007,0.069$ and 0.103 respectively. Hence, following Cohen (1988) guidelines, respective effects sizes of the six exogenous latent variables can be reported as moderate, small, small, very small, very small and small respectively.

\subsection{Hypotheses Testing}

Hypotheses testing for the study is analysed through bootstrapping in SmartPLS 3.0. To run bootstrapping, the researcher used 5,000 samples with the 428 cases.

\subsubsection{Direct Relationship}

Structural model, i.e., path coefficient was tested by using SmartPLS 3.0 to run the PLS Algorithm. Table 6 shows that consumer personal norms towards organic food has a positive and significant impacts on purchase intentions towards organic food $(\beta=0.459, \mathrm{t}=10.843, \mathrm{p}<0.001)$. Therefore, hypothesis 1 is supported.

Further table 6 shows that awareness of consequences $(\beta=0.126, t=3.277, p<0.01)$, injunctive social norms $(\beta=$ $0.166, \mathrm{t}=4.176, \mathrm{p}<0.001)$, environmental concern $(\beta=0.033, \mathrm{t}=1.827, \mathrm{p}<0.05)$, environmental self-identity $(\beta=$ $0.237, t=4.874, p<0.001)$ and aspiration of responsibility $(\beta=0.132, t=5.075, p<0.001)$ shows significantly positive influence on personal norms towards organic food. Hence, H2, H3, H4, H5 and H6 are supported.

Table 6

\begin{tabular}{|c|c|c|c|c|c|c|}
\hline Hypotheses & Relationship & $\begin{array}{l}\text { Beta } \\
\text { Value }\end{array}$ & $\begin{array}{l}\text { Standard } \\
\text { Deviation }\end{array}$ & T Statistics & P Values & Decisions \\
\hline H1 & 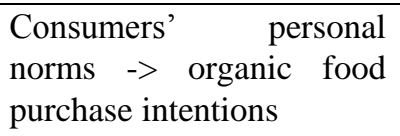 & 0.459 & 0.042 & 10.843 & $0.000 * * *$ & Supported \\
\hline $\mathrm{H} 2$ & $\begin{array}{lr}\text { Awareness } & \text { of } \\
\text { consequences-> } & \text { Personal } \\
\text { norms towards } & \text { organic } \\
\text { food } & \end{array}$ & 0.126 & 0.038 & 3.277 & $0.001 * *$ & Supported \\
\hline $\mathrm{H} 3$ & $\begin{array}{l}\text { Injunctive social norms-> } \\
\text { Personal norms towards } \\
\text { organic food }\end{array}$ & 0.166 & 0.040 & 4.176 & $0.000 * * *$ & Supported \\
\hline $\mathrm{H} 4$ & $\begin{array}{l}\text { Environmental concern-> } \\
\text { Personal norms towards } \\
\text { organic food }\end{array}$ & 0.033 & 0.018 & 1.827 & 0.034 & Supported \\
\hline H5 & $\begin{array}{l}\text { Environmental } \\
\text { self-identity-> } \\
\text { norms towards } \\
\text { food }\end{array}$ & 0.237 & 0.049 & 4.874 & $0.000 * * *$ & Supported \\
\hline
\end{tabular}




\begin{tabular}{|c|c|c|c|c|c|c|}
\hline H6 & $\begin{array}{l}\text { Aspiration } \\
\text { responsibility-> } \\
\text { norms towards } \\
\text { food }\end{array}$ & $\begin{array}{r}\text { of } 0.132 \\
\text { Personal } \\
\text { organic }\end{array}$ & 0.026 & 5.075 & $0.000 * * *$ & Supported \\
\hline
\end{tabular}

Note: $*: \mathrm{p}<0.05, * *: \mathrm{p}<0.01, * * *: \mathrm{p}<0.001$

\subsubsection{Indirect Relationship (Mediation)}

The bootstrapping results, table 7 shows that the consumers' personal norms toward the organic food is a significant mediator for the relationships between awareness of consequences and intention to purchase organic food $(\beta=0.058$, $\mathrm{t}=3.141, \mathrm{p}=0.001)$; injunctive social norms and intention to purchase organic food $(\beta=0.131, \mathrm{t}=4.277, \mathrm{p}=0.000)$; environmental concern and intention to purchase organic food $(\beta=0.033, \mathrm{t}=5.089, \mathrm{p}=0.000)$; environmental self-identity and intention to purchase organic food $(\beta=0.109, \mathrm{t}=1.841, \mathrm{p}=0.030)$; aspiration of responsibility and intention to purchase organic food $(\beta=0.076, \mathrm{t}=5.255, \mathrm{p}=0.000)$. Furthermore, as indicated by Preacher and Hayes (2008), the indirect effect of $95 \%$ bootstrapped confidence interval, as indicated in Table 7, shows that consumer personal norms mediate the relationship between awareness of consequences and purchase intentions towards organic food ( $\mathrm{LL}=0.025, \mathrm{UL}=0.090)$; injunctive social norms and purchase intentions $(\mathrm{LL}=0.089, \mathrm{UL}=0.171$ ); environmental concern and intention to purchase organic food $(\mathrm{LL}=0.008, \mathrm{UL}=0.069)$; environmental self-identity and purchase intentions ( $\mathrm{LL}=0.070, \mathrm{UL}=0.154)$; aspiration of responsibility and purchase intentions ( $\mathrm{LL}=0.046$, $\mathrm{UL}=0.114$ ) because the lower limit (LL) and upper limit (UL) do not straddle a 0 in between the indications. Therefore, H7, H8, H9, H10 and H11 are supported, hence, accepted.

Table 7

\begin{tabular}{|c|c|c|c|c|c|c|c|c|}
\hline \multirow[t]{2}{*}{ Hypotheses } & \multirow[t]{2}{*}{ Relationship } & \multirow[t]{2}{*}{$\begin{array}{l}\text { Beta } \\
\text { Value }\end{array}$} & \multirow[t]{2}{*}{$\begin{array}{l}\text { Std } \\
\text { Dev }\end{array}$} & \multirow[t]{2}{*}{$\begin{array}{l}\text { T } \\
\text { Value }\end{array}$} & \multirow[t]{2}{*}{ P Value } & \multicolumn{2}{|c|}{$\begin{array}{l}\text { Bootstrapped } \\
\text { Confidence Interval }\end{array}$} & \multirow[t]{2}{*}{ Decision } \\
\hline & & & & & & 95\% LL & $95 \% \mathrm{UL}$ & \\
\hline $\mathrm{H} 7$ & $\begin{array}{lr}\text { Awareness } & \text { of } \\
\text { consequences->personal } \\
\text { norms-> } & \text { Purchase } \\
\text { intentions } & \end{array}$ & 0.058 & 0.04 & 3.141 & $0.001 * *$ & 0.025 & 0.090 & Supported \\
\hline $\mathrm{H} 8$ & $\begin{array}{l}\text { Injunctive } \\
\text { norms-> } \\
\text { norms-> } \\
\text { intentions }\end{array}$ & 0.131 & 0.039 & 4.277 & $0.000 * * *$ & 0.089 & 0.171 & Supported \\
\hline H9 & $\begin{array}{l}\text { Environmental concern } \\
\text {-> Personal norms -> } \\
\text { Purchase intentions }\end{array}$ & 0.033 & 0.047 & 5.089 & $0.000 * * *$ & 0.008 & 0.069 & Supported \\
\hline H10 & $\begin{array}{ll}\text { Self-identity } & -> \\
\text { Personal norms } & -> \\
\text { Purchase intentions } & \end{array}$ & 0.109 & 0.039 & 1.841 & $0.030^{*}$ & 0.070 & 0.154 & Supported \\
\hline H11 & $\begin{array}{l}\text { Consumer's aspiration } \\
\text { of responsibility-> } \\
\text { Personal } \\
\text { norms->Purchase } \\
\text { intentions }\end{array}$ & 0.076 & 0.054 & 5.255 & $0.000 * * *$ & 0.046 & 0.114 & Supported \\
\hline
\end{tabular}

Note: $*: \mathrm{p}<0.05, * *: \mathrm{p}<0.01, * * *: \mathrm{p}<0.001$

\subsubsection{Moderating Relationship}

Next this study analyses moderating effect of willingness to pay in terms of its strength between the relationship of 
consumer personal moral norms and intentions to purchase organic food. In this study product indicator approach has been applied through SmartPLS-3. Therefore, estimates are shown in Table 8 after applying the product indicator approach. This approach is used to evaluate the moderating impact of consumer willingness to pay on the relationship between personal norms and purchase intentions towards organic food. It could be recalled that hypothesis 12 stated that consumer product willingness to pay moderates the relationship between consumer personal norms and purchase intentions. The results from Table 8, show that the interaction term (consumer's personal norms $\mathrm{x}$ consumer's product willingness to pay) was positive and significant $(\beta=0.198, \mathrm{t}=2.997, \mathrm{p}=0.001)$, therefore, Hypothesis 12 is supported, hence, accepted.

Table 8. Moderating effects of consumer willingness to pay

\begin{tabular}{lllllll}
\hline Hypothesis & Relationship & $\begin{array}{l}\text { Beta } \\
\text { Value }\end{array}$ & $\begin{array}{l}\text { Standard } \\
\text { Deviation }\end{array}$ & T Statistics & P Values & Decisions \\
\hline H12 & $\begin{array}{l}\text { Consumer's willingness to } \\
\text { pay moderates the } \\
\text { relationship between } \\
\text { personal norms and } \\
\text { organic food purchase } \\
\text { intentions }\end{array}$ & & & & \\
& & & & & \\
&
\end{tabular}

Note: $* *: \mathrm{p}<0.01$

\subsubsection{Assessment of Predictive Relevance $\left(\mathrm{Q}^{2}\right)$}

Statistically a robust structural model must show its ability to display study predictive relevance. Mostly StoneGeisser criterion is used to assess the predictive relevance of the model. According to this criterion inner model should be capable of predicting of endogenous latent constructs (Henseler et al., 2015). In order to perform this test, blindfolding procedure has been followed through SmartPLS-3. The ross validated redundancy measures of endogenous latent construct are represented by $\mathrm{Q}^{2}$ (Hair et al., 2016). The standard value $\mathrm{Q}^{2}$ value must be greater than zero, ensuring that the model has predictive relevance, on the other hand lower $\mathrm{Q}^{2}$ values than 0 showing model lacks predictive relevance (Hair et al., 2016). According to Table 9, $\mathrm{Q}^{2}$ values are more than 0 , where personal norms $(0.164)$ and purchase intentions $(0.142)$. Thus, predictive relevance of the study's model has been established.

Table 9. Cross-Validated redundancies

\begin{tabular}{llll}
\hline Total & SSO & SSE & Predicative Relevance (1-SSE/SSO) \\
\hline Personal norms & 2140.000 & 1790.049 & 0.164 \\
\hline Purchase Intentions & 2568.000 & 2204.248 & 0.142 \\
\hline
\end{tabular}

\section{Discussion}

This study has tested the mediating effects of personal norms on the relationships between awareness of consequences, injunctive social norms, environmental concern, environmental self-identity, aspiration of responsibility and purchase intentions of consumers in organic food context. According to PLS results two-dimensional awareness of consequences, injunctive social norms, environmental concern, environmental self-identity and aspiration of responsibility significantly impacted personal norms, hence, both H2, H3, H4, H5 and H6 were supported; therefore accepted. The findings are as similar with the conclusions made by Shin et al. (2018), Hansen et al. (2018), Joanes (2019) and Shimoda et al. (2019). Additionally, triggered personal norms contribute to organic food purchase intentions. With effective promotional strategies creating consumers' awareness regarding adverse consequences on biosphere and organic food benefits to avert those consequences, acceptable social norms for right thing to do, general consciousness for environmental problems, value based environmental self-identity and consumers' sense of responsibility; could nurture consumers' constructive personal moral norms towards organic food (Steg et al., 2014; Zhao et al., 2019). 
Further, the results reveal that the activated personal norms significantly and positively influenced organic food purchase intentions. Thus, supporting H1, which provide that by creating consumers' intrinsic moral motivation through effective environmental beliefs organic food marketers can create positive purchase intention within consumers for organic food. Hence, creative and effective pro-environmental marketing campaigns based on consumers' moral beliefs and norms can positively create consumers' purchase intentions towards organic food. These findings are consistent with Arvola et al. (2008) and Shin et al. (2018) who proclaimed the positive relationship between personal norms and organic food purchase intentions. Therefore, the realization of consumers' purchase intentions via personal norms are more likely to encourage consumers in their final decision making in Pakistani context. Henceforth, the consumers believe that organic food products ensure not only the environmental preservation but also are considered to be a critical for people health safety. Environmental beliefs ensure the activation of personal norms at initial stages. Particularly the PLS results verify that two-dimensional awareness of consequences (Magnusson et al., 2003) can produce effective intrinsic motivation. Moreover, injunctive social norms that guide social member what is right thing to do in a particular situation also can trigger personal norms as these norms are based on moral and value-based understanding prevailing in the society. The findings are in the line of Matthies et al. (2012). The study results also validate the positive impact of environmental concern on personal norms. Whereas, environmental concern ensures the altruistic behaviour based on selfless and moral values. This finding is in the line with the findings of Steg et al. (2011). Furthermore, environmental self-identity implies activation of personal norms to act in sustainable manners because non-sustainable behaviour threatens valuable self-identity and self-esteem. The results are in the line of the findings of Peloza et al. (2013). PLS results also verdict the activation of personal norms through aspiration of responsibility. Promotion activities based on messages conveying a sense of responsibility among individuals can instigate moral norms among them. The results are in the line with Gao et al. (2017). Hence, H2, H3, H4, H5 and H6 are supported. Additionally, the study also supports the mediating effect of personal norms among the relationship of all suggested environmental belief and organic food purchase intentions, thus, H7, H8, H9, H10 and H11 are accepted. Furthermore, the results also endorse that consumers' willingness to pay moderates positively the link between personal norms and organic food purchase intentions. The results of this study show that Pakistani consumers evaluate organic food morally and emotionally not only rationally, therefore, they are willing to pay even higher prices for environmentally friendly food. This willingness to pay higher prices for organic food instigates the intensity of intrinsic moral motivation towards organic food to buy organic food. The organic food marketers can enhance the effect of personal norms on consumers' purchase intentions towards organic food through promotional activities educating individuals about the features and benefits of organic food consumption, making them indifferent to organic food higher prices. Because paying for environmentally organic food would be in line with their biocentric moral values. It can encourage to consumers to pay more for organic food products. This corroborates findings obtained by Vermeir and Verbeke (2006). Therefore, H12 is supported.

\section{Conclusions and Recommendations}

The results of this research have insinuations for practice and research as organic food buying is getting an issue of great importance in Pakistan. In practical scenario; specifically marketing application, existing results are critical to organic food segmentation, targeting, positioning and promotion of better market demand in organic food context. Personal norms were proved to be prime factor mediated the effect of awareness of consequences, injunctive social norms, environmental concern, environmental self-identity, aspiration of responsibility and purchase intentions regarding organic food. Marketing managers should, therefore, develop various effective strategies to communicate adverse consequences on environment and society due to extensive use of chemically intensive agricultural inputs and resultant food products. It should also be communicated that consumption of organic food would be the right way that consumer should follow as member of society and those must behave in socially responsible manner. Further, with the help of these finding marketers can provide positive recommendations to consumers through marketing and communication channel such as emails, SMS, twitter and Facebook.

As far as theoretical significance is concerned the study involved quantitative research approach with the application of PLS providing a useful apprehension regarding mediating role of personal norms between the link of pro-environmental beliefs and purchase intentions in organic food context. The study outcomes contribute significantly the emerging literature on organic food buying behaviour, which is still under researched area, specifically in Pakistani outlook. As per future research recommendations are concerned the moderating effects of demographic factors can produce important conclusions. As individuals are differentiated in terms of age, gender, education and occupation; such exercise, may find pro-environmental belief as suggested in this study and their 
impact on consumers' personal norms and subsequently on purchase intentions for organic food may fluctuate in the terms of importance. Further, the expansion in existing research model is suggested with variables associated with emotion and habits, and examine at different geographical areas i.e. other sub-continental countries.

\section{References}

Abrahamse, W., et al. (2009). Factors influencing car use for commuting and the intention to reduce it: A question of self-interest or morality?. Transportation Research Part F: Traffic Psychology and Behaviour, 12(4), 317-324. https://doi.org/10.1016/j.trf.2009.04.004

Adesina, A. D. O. (2014). Education and Poverty Alleviation: Problems and Prospects. International Journal of Education and Practice, 2(5), 104-110. https://doi.org/10.18488/journal.61/2014.2.5/61.5.104.110

Al-Swidi, A., et al. (2014). The role of subjective norms in theory of planned behavior in the context of organic food consumption. British Food Journal, 116(10), 1561-1580. https://doi.org/10.1108/BFJ-05-2013-0105

Angbre, F. A. (2016). The Role of Agricultural Education in Ensuring National Security in Nigeria. Agriculture and Food Sciences Research, 3(1), 25-28.

Arvola, A., et al. (2008). Predicting intentions to purchase organic food: The role of affective and moral attitudes in the Theory of Planned Behaviour. Appetite, 50(2-3), 443-454. https://doi.org/10.1016/j.appet.2007.09.010

Asif, M., et al. (2018). Determinant factors influencing organic food purchase intention and the moderating role of awareness: A comparative analysis. Food Quality and Preference, 63, 144-150. https://doi.org/10.1016/j.foodqual.2017.08.006

Bamberg, S., \& Möser, G. (2007). Twenty years after Hines, Hungerford, and Tomera: A new meta-analysis of psycho-social determinants of pro-environmental behaviour. Journal of Environmental Psychology, 27(1), 14-25. https://doi.org/10.1016/j.jenvp.2006.12.002

Barclay, D., et al. (1995). The partial least squares (PLS) approach to casual modeling: personal computer adoption ans use as an Illustration.

Baron, R. M., \& Kenny, D. A. (1986). The moderator-mediator variable distinction in social psychological research: Conceptual, strategic, and statistical considerations. Journal of Personality and Social Psychology, 51(6), 1173.

Basha, M. B., \& Lal, D. (2019). Indian consumers' attitudes towards purchasing organically produced foods: An empirical study. Journal of Cleaner Production, 215, 99-111. https://doi.org/10.1016/j.jclepro.2018.12.098

Berger, I. E., et al. (1994). Subjective product knowledge as a moderator of the relationship between attitudes and purchase intentions for a durable product. Journal of Economic Psychology, 15(2), 301-314. https://doi.org/10.1016/0167-4870(94)90006-X

Beyzavi, M., \& Lotfizadeh, F. (2014). Analyzing the choice behavior based on the theory of consumption values for green products in Iran. Kuwait Chapter of Arabian Journal of Business and Management Review, 33(2572), $1-11$.

Bishop, M. M., \& Barber, N. A. (2015). Should I pay more? The relationship between normative beliefs and willingness-to-pay for organic and local products. Journal of Marketing Theory and Practice, 23(1), 94-106. https://doi.org/10.1080/10696679.2015.980182

Campbell, D. T., \& Fiske, D. W. (1959). Convergent and discriminant validation by the multitrait-multimethod matrix. Psychological Bulletin, 56(2), 81. https://doi.org/10.1037/h0046016

Cestac, J., et al. (2014). Drive as I say, not as I drive: Influence of injunctive and descriptive norms on speeding intentions among young drivers. Transportation Research Part F: Traffic Psychology and Behaviour, 23, 44-56.

Chin, W. W. (1998). Commentary: Issues and opinion on structural equation modelling. JSTOR.

Chin, W. W., et al. (2003). A partial least squares latent variable modeling approach for measuring interaction effects: Results from a Monte Carlo simulation study and an electronic-mail emotion/adoption study. Information Systems Research, 14(2), 189-217. https://doi.org/10.1287/isre.14.2.189.16018

Cialdini, R. B., \& Trost, M. R. (1998). Social influence: Social norms, conformity and compliance.

Cohen, J. (1988). Statistical power analysis for the social sciences.

Cojuharenco, I., et al. (2016). Yes, I can: Feeling connected to others increases perceived effectiveness and socially responsible behavior. Journal of Environmental Psychology, 48, 75-86. 
Davies, J., et al. (2002). Beyond the intention-behaviour mythology: an integrated model of recycling. Marketing Theory, 2(1), 29-113. https://doi.org/10.1177/1470593102002001645

De Groot, J. I., \& Steg, L. (2009). Mean or green: which values can promote stable pro-environmental behavior?. Conservation Letters, 2(2), 61-66. https://doi.org/10.1111/j.1755-263X.2009.00048.x

Dean, M., et al. (2012). The Role of Self-Identity, Past Behavior, and Their Interaction in Predicting Intention to Purchase Fresh and Processed Organic Food. Journal of Applied Social Psychology, 42(3), 669-688.

Ditlevsen, K., et al. (2019). Healthy food is nutritious, but organic food is healthy because it is pure: The negotiation of healthy food choices by Danish consumers of organic food. Food Quality and Preference, 71, 46-53.

Do Paço, A., et al. (2013). Development of a green consumer behaviour model. International Journal of Consumer Studies, 37(4), 414-421. https://doi.org/10.1111/ijcs.12009

Dolnicar, S., \& Grün, B. (2009). Environmentally friendly behavior: Can heterogeneity among individuals and contexts/environments be harvested for improved sustainable management?. Environment and Behavior, 41(5), 693-714. https://doi.org/10.1177/0013916508319448

Doran, R., \& Larsen, S. (2016). The relative importance of social and personal norms in explaining intentions to choose eco-friendly travel options. International Journal of Tourism Research, 18(2), 159-166.

Dunlap, R. E., \& Jones, R. E. (2002). Environmental concern: Conceptual and measurement issues. Handbook of Environmental Sociology, 3(6), 482-524.

Englis, B. G., \& Phillips, D. M. (2013). Does innovativeness drive environmentally conscious consumer behavior?. Psychology \& Marketing, 30(2), 160-172. https://doi.org/10.1002/mar.20595

Fielding, K. S., et al. (2008). Theory of planned behaviour, identity and intentions to engage in environmental activism. Journal of Environmental Psychology, 28(4), 318-326. https://doi.org/10.1016/j.jenvp.2008.03.003

Furlow, N. E., \& Knott, C. (2009). Who's reading the label? Millennials' use of environmental product labels. The Journal of Applied Business and Economics, 10(3), 1.

Gao, J., et al. (2017). Tourists' perceptions of responsibility: an application of norm-activation theory. Journal of Sustainable Tourism, 25(2), 276-291. https://doi.org/10.1080/09669582.2016.1202954

Garedow, B. T., \& Edriss, A. K. (2014). The Dynamics of Land Market and Food Security in Malawi. International Journal of Sustainable Development \& World Policy, 3(5), 115-131.

Gleim, M., \& Lawson, S. J. (2014). Spanning the gap: an examination of the factors leading to the green gap. Journal of Consumer Marketing, 31(6/7), 503-514. https://doi.org/10.1108/JCM-05-2014-0988

Hair Jr, J. F., et al. (2016). A primer on partial least squares structural equation modeling (PLS-SEM). Sage publications.

Han, H., \& Hwang, J. (2015). Norm-based loyalty model (NLM): Investigating delegates' loyalty formation for environmentally responsible conventions. International Journal of Hospitality Management, 46, 1-14.

Han, H., \& Hwang, J. (2016). Cruise travelers' environmentally responsible decision-making: An integrative framework of goal-directed behavior and norm activation process. International Journal of Hospitality Management, 53, 94-105. https://doi.org/10.1016/j.ijhm.2015.12.005

Han, H., et al. (2015). Guests' pro-environmental decision-making process: Broadening the norm activation framework in a lodging context. International Journal of Hospitality Management, 47, 96-107.

Han, H., et al. (2017). Cognitive, affective, normative, and moral triggers of sustainable intentions among convention-goers. Journal of Environmental Psychology, 51, 1-13. https://doi.org/10.1016/j.jenvp.2017.03.003

Han, H., et al. (2019). Word-of-mouth, buying, and sacrifice intentions for eco-cruises: Exploring the function of norm activation and value-attitude-behavior. Tourism Management, 70, 430-443.

Hansen, T., et al. (2018). How the interplay between consumer motivations and values influences organic food identity and behavior. Food Policy, 74, 39-52. https://doi.org/10.1016/j.foodpol.2017.11.003

Hartmann, P., \& Apaolaza-Ibáñez, V. (2012). Consumer attitude and purchase intention toward green energy brands: The roles of psychological benefits and environmental concern. Journal of Business Research, 65(9), 1254-1263. https://doi.org/10.1016/j.jbusres.2011.11.001

He, X., \& Zhan, W. (2018). How to activate moral norm to adopt electric vehicles in China? An empirical study 
based on extended norm activation theory. Journal of Cleaner Production, 172, 3546-3556.

Henseler, J., et al. (2015). A new criterion for assessing discriminant validity in variance-based structural equation modeling. Journal of the Academy of Marketing Science, 43(1), 115-135.

Hornsey, M. J., et al. (2003). On being loud and proud: Non-conformity and counter-conformity to group norms. British Journal of Social Psychology, 42(3), 319-335. https://doi.org/10.1348/014466603322438189

Hustvedt, G., \& Dickson, M. A. (2009). Consumer likelihood of purchasing organic cotton apparel: Influence of attitudes and self-identity. Journal of Fashion Marketing and Management: An International Journal, 13(1), 49-65. https://doi.org/10.1108/13612020910939879

Isola, L. A., Olubukoye, O., Eseosa, O. D., \& Olufemi, O. (2014). Has Financing Poverty Reduction Scheme Help to Alleviate Poverty? Evidence from Nigeria. Humanities and Social Sciences Letters, 2(2), 81-92.

Jacobson, R. P., et al. (2015). Self-control moderates the effectiveness of influence attempts highlighting injunctive social norms. Social Psychological and Personality Science, 6(6), 718-726.

Jain, S. K., \& Kaur, G. (2006). Role of socio-demographics in segmenting and profiling green consumers: an exploratory study of consumers in India. Journal of International Consumer Marketing, 18(3), 107-146.

Joanes, T. (2019). Personal norms in a globalized world: Norm-activation processes and reduced clothing consumption. Journal of Cleaner Production, 212, 941-949. https://doi.org/10.1016/j.jclepro.2018.11.191

Joireman, J. A., et al. (2001). Integrating social value orientation and the consideration of future consequences within the extended norm activation model of proenvironmental behaviour. British Journal of Social Psychology, 40(1), 133-155. https://doi.org/10.1348/014466601164731

Kenny, D. A., \& Judd, C. M. (1984). Estimating the nonlinear and interactive effects of latent variables. Psychological Bulletin, 96(1), 201. https://doi.org/10.1037/0033-2909.96.1.201

Khare, A. (2015). Antecedents to green buying behaviour: a study on consumers in an emerging economy. Marketing Intelligence \& Planning, 33(3), 309-329. https://doi.org/10.1108/MIP-05-2014-0083

Kline, R. B. (1998). Software review: Software programs for structural equation modeling: Amos, EQS, and LISREL. Journal of Psychoeducational Assessment, 16(4), 343-364. https://doi.org/10.1177/073428299801600407

Kumari, P. W. N. A., \& Singhe, P. K. (2014). Poverty Alleviation and Long-Term Sustainability of Microfinance Project: With Special Reference to Matale District. International Journal of Management and Sustainability, $3(2), 84$.

Le Gall-Ely, M. (2009). Definition, measurement and determinants of the consumer's willingness to pay: a critical synthesis and avenues for further research. Recherche et Applications en Marketing (English Edition), 24(2), 91-112. https://doi.org/10.1177/205157070902400205

Lee, R., et al. (2009). The interactions of consumption characteristics on social norms. Journal of Consumer Marketing, 26(4), 277-285. https://doi.org/10.1108/07363760910965873

Li, Q.-C., \& Wu, M.-Y. (2019). Rationality or morality? A comparative study of pro-environmental intentions of local and nonlocal visitors in nature-based destinations. Journal of Destination Marketing \& Management, 11, 130-139. https://doi.org/10.1016/j.jdmm.2019.01.003

Lindenberg, S., \& Steg, L. (2013). Goal-framing theory and norm-guided environmental behavior. Encouraging Sustainable Behaviour, 37-54.

Ling, C. Y. (2013). Consumers' purchase intention of green products: an investigation of the drivers and moderating variable. Elixir Marketing Management, 1, 14503-14509.

Magnusson, M. K., et al. (2001). Attitudes towards organic foods among Swedish consumers. British Food Journal, 103(3), 209-227. https://doi.org/10.1108/00070700110386755

Magnusson, M. K., et al. (2003). Choice of organic foods is related to perceived consequences for human health and to environmentally friendly behaviour. Appetite, 40(2), 109-117.

Mapfumo, A. (2017). Food Security Amongst Small Grains and Long Grains Smallholder Farmers of Masvingo Province in Zimbabwe. Journal of Social Economics Research, 4(2), 22-30.

Markos, D., \& Loha, G. (2016). Sweet potato agronomy research in Ethiopia: Summary of past findings and future research directions. Agriculture and Food Sciences Research, 3(1), 1-11. 
Matthies, E., et al. (2012). The role of parental behaviour for the development of behaviour specific environmental norms-The example of recycling and re-use behaviour. Journal of Environmental Psychology, 32(3), 277-284.

McEachern, M. G., \& Mcclean, P. (2002). Organic purchasing motivations and attitudes: are they ethical?. International Journal of Consumer Studies, 26(2), 85-92. https://doi.org/10.1046/j.1470-6431.2002.00199.x

Misra, R., \& Singh, D. (2016). An analysis of factors affecting growth of organic food: Perception of consumers in Delhi-NCR (India). British Food Journal, 118(9), 2308-2325.

Moser, A. K. (2015). Thinking green, buying green? Drivers of pro-environmental purchasing behavior. Journal of Consumer Marketing, 32(3), 167-175. https://doi.org/10.1108/JCM-10-2014-1179

Nigbur, D., et al. (2010). Attitudes, norms, identity and environmental behaviour: Using an expanded theory of planned behaviour to predict participation in a kerbside recycling programme. British Journal of Social Psychology, 49(2), 259-284. https://doi.org/10.1348/014466609X449395

Nordlund, A. M., \& Garvill, J. (2003). Effects of values, problem awareness, and personal norm on willingness to reduce personal car use. Journal of Environmental Psychology, 23(4), 339-347.

Nsanganzelu, A. J. (2015). Micro-Credits and Poverty Reduction In Dar-Es-Salaam, Tanzania: A Case Study Of Dar-Es-Salaam Commercial Bank. International Journal of Public Policy and Administration Research, 2(1), 1-13. https://doi.org/10.18488/journal.74/2015.2.1/74.1.1.13

Onwezen, M. (2015). I did good, and we did bad: The impact of collective versus private emotions on pro-environmental food consumption. Food Research International, 76, 261-268.

Osterhus, T. L. (1997). Pro-social consumer influence strategies: when and how do they work? Journal of Marketing, 61(4), 16-29. https://doi.org/10.1177/002224299706100402

Oyediran, W. O., Omoare, A. M., \& Osinowo, O. A. (2017). Contributive Roles of Sorghum Production to Food Security and Economic Empowerment of Rural Farming Households in Katsina State, Nigeria. Canadian Journal of Agriculture and Crops, 2(1), 42-49. https://doi.org/10.20448/803.2.1.42.49

Oyediran, W. O., Omoare, A. M., Dick, T. T., \& Shobowale, A. A. (2016). Perception of Youth in Selected Tertiary Institutions on Agricultural Education as a Means of Ensuring Food Security in Ogun State, Nigeria. Journal of Asian Scientific Research, 6(11), 148-157. https://doi.org/10.18488/journal.2/2016.6.11/2.11.148.157

Pakistan Bureau of Statistics (2018). Publications. Retrieved from http://www.pbs.gov.pk/publications.

Pallant, J. (2005). SPSS survival manual: A step by step guide to using SPSS for windows (12th ed.). New South Wales, Australia: Allen \& Unwin.

Paul, J., \& Rana, J. (2012). Consumer behavior and purchase intention for organic food. Journal of Consumer Marketing, 29(6), 412-422. https://doi.org/10.1108/07363761211259223

Peattie, K. (2001). Golden goose or wild goose? The hunt for the green consumer. Business Strategy and the Environment, 10(4), 187-199. https://doi.org/10.1002/bse.292

Peirovedin, M. R., Mahdavi, M., \& Ziyari, Y. A. (2016). An analysis of effective factors on spatial distribution of poverty in rural regions of Hamedan Province. International Journal of Geography and Geology, 5(5), 86-96.

Peloza, J., et al. (2013). Good and guilt-free: The role of self-accountability in influencing preferences for products with ethical attributes. Journal of Marketing, 77(1), 104-119. https://doi.org/10.1509/jm.11.0454

Persaud, A., \& Schillo, S. R. (2017). Purchasing organic products: role of social context and consumer innovativeness. Marketing Intelligence \& Planning, 35(1), 130-146. https://doi.org/10.1108/MIP-01-2016-0011

Polonsky, M. J. (1994). An introduction to green marketing. Electronic Green Journal, 1(2).

Preacher, K. J., \& Hayes, A. F. (2008). Asymptotic and resampling strategies for assessing and comparing indirect effects in multiple mediator models. Behavior Research Methods, 40(3), 879-891.

Rahman, M. A., \& Ahamat, H. (2018). Food Security Implementation in ASEAN: Towards Sustainable Food Trade and Food Market within the ASEAN Economic Community. International Journal of Asian Social Science, 8(7), 434-447. https://doi.org/10.18488/journal.1.2018.87.434.447

Ram, R. (2015). Income elasticity of poverty: estimates for South Asian countries. The Economics and Finance Letters, 2(1), 1-7. https://doi.org/10.18488/journal.29/2015.2.1/29.1.1.7

Raza, H., Mohiuddin, Z. A., Zaidi, S. S. Z., \& Osama, A. (2018). CPEC: Pakistan-China Cordial Ties-A Boost to 
Pakistan's Economy. Journal of Accounting, Business and Finance Research, 2(1), 1-6. https://doi.org/10.20448/2002.21.1.6

Rigdon, E. E., et al. (1998). A comparative review of interaction and nonlinear modeling. Interaction and Nonlinear Effects in Structural Equation Modeling, 1-16. https://doi.org/10.4324/9781315092614-1

Roitner-Schobesberger, B., et al. (2008). Consumer perceptions of organic foods in Bangkok, Thailand. Food Policy, 33(2), 112-121. https://doi.org/10.1016/j.foodpol.2007.09.004

Sandhu, Y. A., et al. (2018). An Exploratory Investigation of Consumer Motives and Impeding Barriers to Buying Organic Food Products in Pakistan. Pacific Business Review International, 11(3), 128-136.

Schiffman, L., \& Wisenblit, J. (2015). Consumer Behavior (Vol. 11). England Pearson Education Limited.

Schultz, P. W. (2001). The structure of environmental concern: Concern for self, other people, and the biosphere. Journal of Environmental Psychology, 21(4), 327-339. https://doi.org/10.1006/jevp.2001.0227

Schultz, P. W., et al. (2005). Values and their relationship to environmental concern and conservation behavior. Journal of Cross-Cultural Psychology, 36(4), 457-475. https://doi.org/10.1177/0022022105275962

Schwartz, S. H. (1977). Normative influences on altruism. Advances in Experimental Social Psychology, 10, 221-279. https://doi.org/10.1016/S0065-2601(08)60358-5

Shah Alam, S., \& Mohamed Sayuti, N. (2011). Applying the Theory of Planned Behavior (TPB) in halal food purchasing. International Journal of Commerce and Management, 21(1), 8-20.

Shimoda, A., et al. (2019). Our health, our planet: a cross-sectional analysis on the association between health consciousness and pro-environmental behavior among health professionals. International Journal of Environmental Health Research, 1-12. https://doi.org/10.1080/09603123.2019.1572871

Shin, Y. H., et al. (2018). The theory of planned behavior and the norm activation model approach to consumer behavior regarding organic menus. International Journal of Hospitality Management, 69, 21-29.

Smith, J. R., et al. (2012). Congruent or conflicted? The impact of injunctive and descriptive norms on environmental intentions. Journal of Environmental Psychology, 32(4), 353-361.

Sparks, P., \& Shepherd, R. (2002). The role of moral judgments within expectancy-value-based attitude-behavior models. Ethics \& Behavior, 12(4), 299-321. https://doi.org/10.1207/S15327019EB1204_01

Spash, C. L., et al. (2009). Motives behind willingness to pay for improving biodiversity in a water ecosystem: Economics, ethics and social psychology. Ecological Economics, 68(4), 955-964.

Steg, L., \& De Groot, J. (2010). Explaining prosocial intentions: Testing causal relationships in the norm activation model. British Journal of Social Psychology, 49(4), 725-743. https://doi.org/10.1348/014466669XX77745

Steg, L., et al. (2011). General antecedents of personal norms, policy acceptability, and intentions: the role of values, worldviews, and environmental concern. Society and Natural Resources, 24(4), 349-367.

Steg, L., et al. (2014). An integrated framework for encouraging pro-environmental behaviour: The role of values, situational factors and goals. Journal of Environmental Psychology, 38, 104-115.

Steg, L., et al. (2014). The significance of hedonic values for environmentally relevant attitudes, preferences, and actions. Environment and Behavior, 46(2), 163-192. https://doi.org/10.1177/0013916512454730

Stern, P. C., \& Dietz, T. (1994). The value basis of environmental concern. Journal of Social Issues, 50(3), 65-84.

Stern, P. C., et al. (1999). A value-belief-norm theory of support for social movements: The case of environmentalism. Human Ecology Review, 81-97.

Tabachnick, B., et al. (2012). Chapter 13: principal components and factor analysis. Using Multivariate Statistics. London: Pearson.

Thøgersen, J., et al. (2015). Consumer buying motives and attitudes towards organic food in two emerging markets: China and Brazil. International Marketing Review, 32(3/4), 389-413. https://doi.org/10.1108/IMR-06-2013-0123

Trivedi, R. H., et al. (2015). Pro-environmental behaviour, locus of control and willingness to pay for environmental friendly products. Marketing Intelligence \& Planning, 33(1), 67-89. https://doi.org/10.1108/MIP-03-2012-0028

Tully, S. M., \& Winer, R. S. (2014). The role of the beneficiary in willingness to pay for socially responsible 
products: a meta-analysis. Journal of Retailing, 90(2), 255-274. https://doi.org/10.1016/j.jretai.2014.03.004

Tung, S.-J., et al. (2012). Attitudinal inconsistency toward organic food in relation to purchasing intention and behavior: An illustration of Taiwan consumers. British Food Journal, 114(7), 997-1015.

Van der Werff, E., et al. (2013). The value of environmental self-identity: The relationship between biospheric values, environmental self-identity and environmental preferences, intentions and behaviour. Journal of Environmental Psychology, 34, 55-63. https://doi.org/10.1016/j.jenvp.2012.12.006

Vermeir, I., \& Verbeke, W. (2006). Sustainable food consumption: Exploring the consumer "attitude-behavioral intention" gap. Journal of Agricultural and Environmental Ethics, 19(2), 169-194.

Vermeir, I., \& Verbeke, W. (2008). Sustainable food consumption among young adults in Belgium: Theory of planned behaviour and the role of confidence and values. Ecological Economics, 64(3), 542-553.

Voon, J. P., et al. (2011). Determinants of willingness to purchase organic food: An exploratory study using structural equation modeling.

Voorhees, C. M., et al. (2016). Discriminant validity testing in marketing: an analysis, causes for concern, and proposed remedies. Journal of the Academy of Marketing Science, 44(1), 119-134.

Wee, C. S., et al. (2014). Consumers perception, purchase intention and actual purchase behavior of organic food products. Review of Integrative Business and Economics Research, 3(2), 378.

White, K., \& Simpson, B. (2013). When do (and don't) normative appeals influence sustainable consumer behaviors? Journal of Marketing, 77(2), 78-95. https://doi.org/10.1509/jm.11.0278

Whitmarsh, L., \& O'Neill, S. (2010). Green identity, green living? The role of pro-environmental self-identity in determining consistency across diverse pro-environmental behaviours. Journal of Environmental Psychology, 30(3), 305-314. https://doi.org/10.1016/j.jenvp.2010.01.003

World Bank. (2013). World Bank Open Data. Retrieved from https://data.worldbank.org/country/pakistan

Yadav, R., \& Pathak, G. S. (2016). Intention to purchase organic food among young consumers: Evidences from a developing nation. Appetite, 96, 122-128. https://doi.org/10.1016/j.appet.2015.09.017

Yadav, R., \& Pathak, G. S. (2017). Determinants of consumers' green purchase behavior in a developing nation: Applying and extending the theory of planned behavior. Ecological Economics, 134, 114-122.

Zanoli, R. (2004). The European Consumer and Organic Food. School of Management and Business, Wales.

Zepeda, L., \& Li, J. (2007). Characteristics of organic food shoppers. Journal of Agricultural and Applied Economics, 39(1), 17-28. https://doi.org/10.1017/S1074070800022720

Zhao, C., et al. (2019). Exploring the influence of severe haze pollution on residents' intention to purchase energy-saving appliances. Journal of Cleaner Production, 212, 1536-1543.

\section{Appendix}

\begin{tabular}{ll}
\hline Constructs & Adapted From \\
\hline Purchase Intentions & Wee et al. (2014) \\
\hline I will buy organic food products in the near future & \\
\hline I plan to buy organic food products on regular basis & \\
\hline I plan to buy organic food products for my long-term health benefits & \\
\hline I plan to buy organic food products because those are more concerned about food & \\
safety & Abrahamse et al. (2009) \\
\hline I plan to buy organic food products because those are more environmentally friendly & \\
\hline I plan to buy organic food products because I am concerned about animal welfare & \\
\hline Personal norms & \\
\hline I feel an obligation to purchase organic food rather than non-organic food & \\
\hline
\end{tabular}




\section{Constructs}

\section{Adapted From}

Consuming organic food rather than non-organic food makes me feel like a better person

If I consume organic food rather than non-organic food, I feel as if I am making an individual contribution to something better

I feel morally obliged to purchase environmentally friendly organic food products, regardless of what other people do

I feel guilty when I purchase environmentally harmful products

I would consider myself a better person if I purchase environmentally friendly organic food products

\section{Consumer willingness to pay}

It is acceptable to pay a premium to buy organic food

I am intending to spend extra in order to buy organic food

I am intending to pay more for organic food

I feel proud to have environmentally friendly food in my house though they costlier to conventional food

\section{Awareness of Consequences}

When I purchase organic food, it is important to me that this helps to

Reduce the amount of chemicals that run-off into lakes and watercourses (ACEnv)

Reduce the use of artificial fertilisers in agriculture (ACEnv)

Reduce the use of anti-weed chemicals and pesticides in agriculture (ACEnv)

Reduce the pollution of the soil (ACEnv)

Reduce the medication of farm animals (ACEnv)

Improve the general state of the environment (ACEnv)

Improve health of the domestic animals (ACEnv)

Preserve biodiversity in nature (ACEnv)

Improves the people health (ACSoc)

Give myself a good conscience (ACSoc)

Reduce the risk for illness in people (ACSoc)

Give my family better food (ACSoc)

Avoid risks that may be associated with eating non-organic foods (ACSoc)

\begin{tabular}{ll}
\hline Injunctive Social Norms & Vermeir and Verbeke \\
& $(2008)$
\end{tabular}

My family thinks I should buy organic food

My friends expect me to buy organic food

People, who influence my buying behaviour, think I ought to buy organic food

Many people in the society think I should buy organic food

People who are important to me expect me to buy organic food

\section{Environmental Concern}

The delicate balance of the nature can be easily upset

Human beings are severely abusing the environment 


\section{Constructs}

\section{Adapted From}

Humans must maintain the balance with nature in order to survive

Human interferences with nature often produce disastrous consequences

The earth is like a spaceship with limited room and resources

\section{Environmental self-identity}

Hustvedet (2009)

I think of myself as an environmental consumer

I am a socially responsible consumer who buy organic food

I think of myself as someone who is concerned about environmental issues

I think of myself as an organic food consumer

I think of myself as someone who is concerned about unhealthy food issues

Aspiration of Responsibility

Han et al. (2016)

I believe that every food buyer is partly liable for environmental problems caused by chemically intensive conventional food products

I feel that every food buyer is jointly liable for the environmental deteriorations caused by chemically intensive conventional food products

Every food buyer must take responsibility for the environmental problems caused by chemically intensive conventional food products

I feel an obligation to choose organic food instead of a conventional one when deciding on buying food product

Regardless of what other people do, because of my own values/principles I feel that I should behave in an environmentally friendly way while buying food products 